\title{
THE ROBATHIN V AUSTRIA RULING BY THE EUROPEAN COURT OF HUMAN RIGHTS: SOME PRELIMINARY CONSIDERATIONS FROM A COMPETITION LAW PERSPECTIVE
}

\author{
Pablo Figueroa Regueiro \\ and \\ Yulia Tosheva \\ Gibson, Dunn \& Crutcher LLP ${ }^{1}$
}

Summary. 1. Introduction. 2. The Facts. 2.1. The Pleadings of the Applicant.
2.2. The Submissions of the Austrian Government. 3. The Actual Ruling of the
ECtHR. 4. Conclusions.

\section{INTRODUCTION.}

In a ruling of 3 July 2012 in case Robathin v Austria ${ }^{2}$ (the «Robathin» ruling), the European Court of Human Rights (the «ECtHR») established that certain searches and seizures of electronic data which had been carried out by Austrian policemen at a lawyer's office constituted a breach of the latter's right to privacy as recognized by Article 8 of the European Convention on Human Rights (the «ECHR»). ${ }^{3}$

The case concerned a criminal investigation into alleged theft and embezzlement. However, given that the relatively sweeping safeguards provided for in Austrian law for the proper copying of electronic documents were considered by the ECtHR to be insufficient in order to ensure compliance with the ECHR, the ruling has the potential to have widespread repercussions for antitrust dawn raids practice at both the $\mathrm{EU}^{4}$ and national level. In

${ }^{1}$ Pablo Figueroa (LL.M., Bruges and Cornell) and Yulia Tosheva (LL.M., King's College) are, respectively an associate and a trainee at the Brussels office of Gibson, Dunn \& Crutcher LLP. The authors are grateful to Elsa Sependa, also an associate from the Brussels of Gibson, Dunn \& Crutcher LLP and to Jesús Alfaro, from Linklaters LLP, Pedro Suárez, from Ramón y Cajal Abogados, Luis Gordillo, from the Universidad de Deusto, and José Antonio Rodríguez-Míguez, from the Galician Competition Authority, for their comments. However, any remaining mistake is of the authors.

2 See Judgment of the European Court of Human Rights of 3 July 2012, Robathin $v$ Austria (the «Robathin» ruling).

3 See European Convention for the Protection of Human Rights and Fundamental Freedoms (the «ECHR») of 4 November 1950, Rome, at article 8.

${ }^{4}$ Although some might argue that for an Act of the Commission to constitute a breach of the ECHR it has to constitute a «manifest breach» of the ECHR, in application of the socalled Bosphorus test (see the Ruling of the ECtHR of 30 June 2005 Bosphorus 453036/98 
particular, the applicable Austrian procedures included (i) an obligation to store the copied documents on discs which were to be sealed and brought before a judge for a decision as to whether or not they could be relied on as evidence and (ii) the presence, during the searches, of a representative of the relevant Bar association. ${ }^{5}$

The Robathin judgment confirms the established practice of both the ECtHR $^{6}$ and Court of Justice of the European Union ${ }^{7}$ (the «CJEU»), according to which searches undertaken by public authorities should not impinge on or restrict in an unnecessary or disproportionate manner fundamental rights, including professional secrecy, ${ }^{8}$ which are protected by both the ECHR and European law. More specifically, the judgment clearly condemns «general searches» of electronic documents which are not «reasonably limited» in their scope, ${ }^{9}$ on the basis that they unduly interfere with the right to privacy protected by Article 8 ECHR. According to the principle of proportionality, which is of course both a general principle of EU law ${ }^{10}$ and a key

and GoRDILLo, L.I., Interlocking Constitutions. Towards an Interordinal Theory of National, European and UN Law, Hart Monographies in Transnational and International Law, 2012, at pp. 147 ff; see further inter alia, JACQUÉ, J.P., « Droit Communautaire et Convention Européenne des droits de l'homme, l'arrêt Bosphorus, une jurisprudence 'Solange II' de la Cour des droits de l'homme?» (2005) 41(3) Revue Trimestrielle de Droit Européen 756; Contastantinesco, V., «C'est comme si c'était fait? Observations à propos de l'arret de Cour européenne des droits de l'homme (grand chambre), Bosphorus airlines, du 30 juin 2005» (2006) 42(3-4) Cahiers de droit Européen 363). On the impact of the formal accession of the EU to the ECHR see inter alia, GordiLLo, L., «Un paso más hacia la estabilización delas relaciones interordinamentales en Europa: la Incorporación de la UE al CEDH» (2011) 38 Revista Española de Derecho Europeo 173.

5 See Robathin, at para. 48.

${ }^{6}$ See Judgment of the European Court of Human Rights, 16 July 2012, Societe Colas Est $v$ France, at para. 43.

7 See Case 46/87 Hoechst AG v Commission of the European Communities, at para. 19.

${ }^{8}$ Note that in this case the Court analysed legal privilege as deriving from the right to privacy guaranteed by Article $8 E C H R$, whereas other rulings by the ECtHR derive the right to privacy from the right to due process guaranteed by Article $6 \mathrm{ECHR}$, e.g., Judgment of the European Court of Human Rights, 28 November 1991, S v Switzerland, at para 48, and Judgment of the European Court of Human Rights, 25 March 1992, Campbell $v$ the United Kingdom, at para. 46. For another example where the ECtHr analysed professional secrecy under Article 8 (privacy) see, e. g., Judgment of the European Court of Human Rights, 25 March 1998 Kopp v Switzerland, at para. 75.

9 See Robathin, at para. 44.

10 The CJEU recognised proportionality as a general principle of EU law in Case 4/73 Nold v Commission [1974] ECR 491, at pp. 513-514. See further the Charter of Fundamental Rights of the European Union, OJ C 364/1, 18 December 2000, at para. 49. See Tridimas, T., The General Principles of EU Law, Oxford 2006, at pp. $136 \mathrm{ff}$. See further Dashwood, A., Dougan, M., Rodger, B., Spaventa, E., and Wyatt, D., Wyatt and 
principle in the interpretation of the rights recognized by the ECHR, ${ }^{11}$ any measure imposed by a public authority should be strictly necessary to attain a legitimate aim.

Another important issue raised by the judgment is the extent to which courts (and, it is probably to be inferred by analogy, administrative bodies, including competition authorities $)^{12}$ enjoy a margin of appreciation when determining the scope of search warrants i.e., how broadly a warrant could be formulated without breaching the principle of proportionality. Interestingly, the Strasbourg Court considered to be «couched in very broad terms», ${ }^{13}$ a Court warrant allowing for the «search and seizure of [...] documents, personal computers and discs, bank documents, deeds of gift and will in favour of Dr Heinz Robathin, and any files concerning [two named individuals]». ${ }^{14}$ According to the ECtHR, the warrant should have indicated the reasons why «a search of all the Applicant's data was necessary for the investigation». ${ }^{15}$ In our experience, it is not unheard of for court warrants authorizing competition law inspections to be couched in similar or even broader terms.

\section{THE FACTS.}

The case originated in an application against the Republic of Austria lodged before the ECtHR by an Austrian lawyer. The applicant alleged that the search and seizure of electronic data from his law office had violated his right to privacy in breach of Article 8 ECHR. The search of the applicant's business premises was conducted in the presence of the applicant, his defence counsel and a repre-

Dashwood's European Union Law, Hart Publishing, 2011, at pp. 121-124.

${ }_{11}$ According to settled case-law of the ECtHR, a limitation to the rights enshrined in the ECHR will not be compatible with Article 6 of the ECHR, if it does not pursue a legitimate aim and if there is no reasonable relationship of proportionality between the means employed and the aim sought to be achieved. See, e.g., Judgment of the European Court of Human Rights, 23 March 2010, M.A.K. and R.K. v the United Kingdom, at para. 42, and Judgment of the European Court of Human Rights, 28 May 1985, Ashingdane $v$ the United Kingdom, at para. 57. See further, McBRIDE J., «Proportionality and the European Convention on Human Rights», The principle of Proportionality in the Laws of Europe, Hart Publishing 1999, at pp. 23-24. The ECtHR has repeatedly established that the concept of «necessary in a democratic society» is to be interpreted restrictively (see, e.g., Judgment of the European Court of Human Rights of 26 April 1979 in Case Sunday Times and Judgment of the European Court of Human Rights of 25 February 1993 in case Miliailhe).

12 That would probably be the case, e.g., of the Orders by the Spanish Directorate for Intestigation («Dirección de Investigatión») of the Spanish Competition Authority (the «Comisión Nacional de la Competencia») authorising inspections, see Article 40(1) of Act 15/2007, of 3 July, on the Defence of Competition.

13 See Robathin, at para. 50.

14 See Robathin, at para. 8.

15 See Robathin, at para. 51. 
sentative of the Vienna Bar Association. The police officers had searched the applicant's computer system "copying all files» from the applicant's computer system. ${ }^{16}$ The representative of the Vienna Bar Association had opposed this as being disproportionate since «it was technically possible, by using appropriate search criteria, to search for and copy only those files which corresponded to the criteria set out in the search warrant $\gg .{ }^{17}$ The disks in which the information was copied were sealed and were handed to an investigative judge. ${ }^{18}$

\subsection{The Pleadings of the Applicant.}

The applicant submitted to the ECtHR that, under the Austrian Lawyers Act (the «Rechtsanwaltsordnung»), ${ }_{10}^{19}$ he was bound by a duty of professional secrecy in respect of information which became known to him in the course of the exercise of his profession, and that the principle of secrecy must not be circumvented by seizures of documents such as those undertaken by the Austrian police. According to the applicant, «the search and seizure warrant had been vague and could not be considered to be in accordance with the law, or, in the alternative, the search and seizure of all his law office 's electronic data could not be considered proportionate and had thus not been necessary in a democratic society..${ }^{20}$

\subsection{The Submissions of the Austrian Government.}

The Austrian Government argued that while the principle of professional secrecy as expressed in the Lawyers Act served to protect the special relationship of confidence between a lawyer and a client, professional secrecy did not protect the lawyer himself against criminal prosecution or measures in connection with such prosecution. It should be noted that the lawyer was suspected, inter alia, of having stolen furniture, pictures and silver and of having abused certain powers of attorney. ${ }^{21}$ As to the applicant's claim that the examination of all his files had been excessive and disproportionate, the Government submitted that «in order to determine what was of relevance to the criminal proceedings, all the seized data had had to be searched, as some relevant documents might not have been detected by a comprehensive full-text search alone..$\rangle^{22}$

\section{THE ACTUAL RULING OF THE ECTHR.}

In its assessment, the ECtHR thoroughly examined whether the measure in question was "necessary in a democratic society», in other words,

\footnotetext{
${ }^{16}$ See Robathin, at para. 10.

17 Ibid.

18 See Robathin, at paras 10 and 12.

19 See Austrian Lawyers Act No. 96/ 1868 (the «Rechtsanwaltsordnung»), at section 9.

${ }^{20}$ See Robathin, at para. 33.

${ }^{21}$ See Robathin, at para. 9

${ }^{22}$ See Robathin. at para. 49.
} 
«whether the relationship between the aim sought to be achieved and the means employed can be considered proportionate». ${ }^{23}$ The elements which the Court took into consideration in its assessment were: (i) whether the search was based on a warrant issued by a judge and based on a reasonable suspicion; (ii) whether the scope of the warrant was reasonably limited; and (iii) whether the search had been carried out in the presence of an independent observer in order to ensure that materials subject to professional secrecy had not been removed. ${ }^{24}$

In the circumstance of the Robathin case, the ECtHR was satisfied that the Austrian search warrant had been issued by a judge and was based on reasonable suspicion. Turning to the question of whether the scope of the warrant was reasonably limited, the Court considered that the search warrant "was couched in very broad terms». ${ }^{25}$ In particular, the warrant authorized «in a general and unlimited manner the search and seizure of documents, personal computers and discs, savings books, bank documents and deeds of gift and wills in favour of the applicant. $\gg{ }^{26}$ Finally, the ECtHR concluded that «the seizure and examination of all data went beyond what was necessary to achieve the legitimate aim $\rangle^{27}$ of the inspection, therefore, there was a violation of Article 8 of the ECHR.

\section{CONCLUSIONS.}

An important question deriving from the Robathin ruling is what limitations the EU Commission and the national competition authorities face when conducting inspections.

The Robathin ruling confirms that, as has been previously argued by one of the authors ${ }^{28}$ and other competition practitioners, ${ }^{29}$ the principle of proportionality plays a key role when setting the limits of the authorities' powers. If an investigatory measure limits fundamental rights protected by the ECHR and is not strictly necessary for the purposes of the investigation,

${ }^{23}$ See Robathin, at para. 43.

${ }^{24}$ See Robathin, at para. 44.

${ }^{25}$ See Robathin, at para. 47.

26 See Robathin, at para. 47.

27 See Robathin, at para. 52.

${ }^{28}$ See Figueroa, P. and Acinas, J., "Inspecciones domiciliarias de la Comisión Nacional de la Competencia: unas brevísimas consideraciones al hilo de la Sentencia de la Audiencia Nacional de 30 de septiembre de 2009", Gaceta jurídica de la Unión Europea $y$ de la competencia, $\mathrm{N}^{\circ} 16,2010$.

29 See, e.g., Gutiérrez, A., and Lorente, F., «Inspecciones de competencia y su control judicial: aspectos constitucionales y penales», Actualidad Jurídica Uría Menéndez, n. ${ }^{\circ} 252010$. 
it will constitute a breach of the ECHR (and, in all likelihood, of EU law).$^{30}$ In its assessment in the Robathin ruling, the ECtHR repeatedly ${ }^{31}$ referred to its seminal judgment in Société Colas Est v France ${ }^{32}$ concerning dawn raids on 56 construction companies conducted by the French competition authority. As is well known, in the latter case the authority's officials had, without any judicial authorization, entered the undertakings' premises and seized thousands of documents in the context of a large-scale investigation into a suspected public procurement cartel. According to the French Government the officials had only exercised their right of inspection in accordance with national laws and no «general searches» had been carried out. ${ }^{33}$ In its assessment, the ECtHR held that the French authorities «had very wide powers» under national laws giving them "exclusive competence to determine the expediency, number, length and scale of inspections» and that the inspections could not be regarded "as strictly proportionate to the legitimate aims pursued». ${ }^{34}$ In other words, the lawfulness of a certain act conducted by a competition authority during a dawn raid will hinge on a case-by-case application of the general principle of proportionality.

It is notable that in its assessment, the ECtHR followed a line of reasoning it has already endorsed in the Iliya Stefanov v. Bulgaria judgment. ${ }^{35} \mathrm{In}$ the latter case, also concerning, inter alia, the search and seizure of electronic data from a lawyer's computer, the ECtHR held in clear terms that "search warrants have to be drafted, as far as practicable, in a manner calculated to keep their impact within reasonable bounds» and emphasized that "[t] his is all the more important in cases where the premises searched are the office of a lawyer, which as a rule contains material which is subject to legal professional privilege. ${ }^{36}$ As we indicated above, one cannot but hope that national courts will take due note of these principles when considering

${ }^{30} \mathrm{Be}$ it in the form of a breach of General Principles of EU law, whose content is usually determined, inter alia, by reference to the ECHR (see, e.g., Case 36/75 Rutiliv Minister for the Interior [1975] ECR 1219) or as a breach of the Charter, which essentially mirrors the ECHR. As expressly stated in Recital 5 of the Preamble of the Charter, the Charter does not create new rights but only reaffirms the rights as they result from, inter alia, the ECHR and the case-law of the ECtHR.

${ }^{31}$ Robathin, at paras. 40 and 44.

32 See Judgment of the European Court of Human Rights, 16 July 2012, Societe Colas Est $v$ France, at para. 43.

33 See Robathin, at para. 45.

${ }^{34}$ Robathin, at para. 49.

35 See Judgment of the European Court of Human Rights of 22 May 2008, Iliya Stefanov $v$ Bulgaria, at paras. 31-45.

${ }^{36}$ Robathin, at para. 41. 
and drafting warrants which authorise competition authorities to conduct on-spot investigations.

Some might argue that the Court's reasoning in the Robathin ruling is informed by the fact that the documents copied were located in the premises of a law firm. However, while competition authorities probably face heightened duties when conducting dawn raids in the premises of law firms (something which the European Commission has done in the past), the Stefanov ruling mentioned above clearly indicates that the fact that the documents are in a law firm is important because it then becomes more likely that they will encounter materials that are subject to legal professional privilege. However, this rationale presumably also applies to many non-lawyers (CEOs, senior directors of companies, etc.). In any event, the Robathin ruling makes it clear that the obligation to impose reasonable limits on the scope of a warrant applies irrespective of whether the search of a lawyer's office is concerned. The language used by the ECtHR seems to us extremely clear in this regard. In the words of the Court:

«Elements taken into consideration [when ascertaining whether a measure is 'necessary in a democratic society] are, in particular, whether the search was based on a warrant issued by a judge and based on reasonable suspicion, whether the scope of the warrant was reasonably limited, and where the search of a lawyer's office was concerned - whether the search was carried out in the presence of an independent observer in order to ensure that materials subject to professional secrecy were not removed». ${ }^{37}$

In other words, only the later of the guarantees is (arguably) limited in its application to searches conducted in the premises of a lawyer.

TITLE: The Robathin v Austria Ruling by the European Court of Human Rights: Some Preliminary Considerations from a Competition law Perspective.

RESUMEN: Este artículo analiza el caso Robathin v Austria del TEDH, en el que se estableció que ciertas investigaciones e incautaciones de datos electrónicos llevados a cabo por la policía austríaca en el despacho de un abogado resultaron contrarios al artículo 8 del Convenio.

PALABRAS CLAVE: TEDH, CEDH, intimidad, derecho de la competencia.

ABSTRACT: This article analyses the case Robathin $v$ Austria where the ECtHR established that certain searches and seizures of electronic data which had been carried out by Austrian policemen at a lawyer's office constituted a breach of the latter's right to privacy as recognized by Article 8 of the European Convention on Human Rights.

KEY WORDS: ECtHR, ECHR, privacy, antitrust law.

Recibido: 07.09.2012

Aceptado: 18.01.2013

${ }^{37}$ See Robathin, at para. 44 (emphasis added). 